\title{
The Significance of the Body in Zora Neale Hurston's Their Eyes Were Watching God: A Cixousian Reading
}

\author{
Iran Zamani \\ Islamic Azad University-Central Tehran Branch, Iran \\ E-mail: izirmani390@gmail.com
}

Received: 30-04-2013

Accepted: 05-06-2013

Published: 01-07-2013

doi:10.7575/aiac.ijalel.v.2n.4p.240

URL: http://dx.doi.org/10.7575/aiac.ijalel.v.2n.4p.240

\begin{abstract}
The purpose of the current paper is studying Zora Neale Hurston's masterpiece in the light of the post-structuralist feminist theories of the French philosopher, writer and critic Hélène Cixous. The article aims at scrutinizing the concept of body which is an integral part of écriture féminine. In order to accomplish this investigation, the researcher attempts to present manifestations of corporeality through the course of the selected novel which is Their Eyes Were Watching God. The fact that Hurston's involvement in adapting the notion of corporeality is evident to the point that some scholars approve of her obsession with the mentioned issue may serve as a proof of the fruitfulness of this research. The present article encompasses examining Hurston's attitude toward the selected concept, working with the selected text and taking the female characters and their deeds under consideration in order to grasp the desirable result.
\end{abstract}

Keywords: Zora Neale Hurston, Hélène Cixous, Their Eyes Were Watching God, écriture féminine, body, corporeality

\section{Introduction}

\subsection{Literary Overview}

Zora Neale Hurston, the distinguished and prizewinning author, wrote her well-known masterpiece Their Eyes Were Watching God (2006) in Haiti just over a seven-week period. According to King (2008), many fictions of the earlier twentieth century written by African Americans were meant to present their protagonists' longing and quest in the process of becoming a full and intelligent human being (p. 18). Hurston's magnum opus is capable to be categorized under this group of works. Their Eyes Were Watching God is a highly sensual text as a result of its numerous references to corporeality and portrayal of human's longings. Indeed, it bears the capability to be considered as a highly sensual text in the time of its publication that was 1937. In King's viewpoint (2008) Hurston portrays Janie as a "desiring subject who insists on making sexual expression as a part of her quest for experience and self-knowledge" (p. 26). This means that issues such as sexuality and gender are among the integral aspects of one's self. Therefore, an extensive knowledge of the mentioned issues is required to actualize one's self.

\subsection{Theoretical Background}

Post-structuralist French feminism is highly influenced by Lacanian psychoanalysis, thus it proposes quite distinctive ideas about the issues of sexuality and desire. The most leading theoreticians of this critical field are Irigaray, Kristeva and Cixous who strive for a new female identity, writing and language in order to subvert the phallogocentric structures of culture and identity.

This paper focuses on Hélène Cixous's perspectives. Her momentous policy is hostility toward the patriarchal binary oppositions. Furthermore, she has declared a feminine practice of writing which is closely connected to body. Regarding the fact that she views feminine sexuality as multiple and resourceful, she favors multiplicity and believes that feminine libido is closely connected to writing.

Cixous proposes the idea of écriture féminine which tries to dismantle all sorts of cultural oppressions by means of creating a subversive language. This language flourishes from body, generates proliferating meaning and is not included within the dominant discourse. Thus, feminine writing is capable to be regarded as a locus for the marginal. These characteristics lead feminine writing to refuse censorship. As a consequence, this mode of writing and criticism is helpful in revealing what women have been always deprived of.

Thus far, this section has debated the essence of écriture féminine briefly. According to the previous discussion, the major traits of this mode of writing and criticism includes concentration on body and physicality, dealing with the plural rather than the singular, concern with creativity, otherness and openness in addition to resisting authority. Therefore, the concept of body gains a notable significance within cixous's theoretical and poetical writings or as Mary Eagleton (2000) argues "concern with physicality and body" is a prevalent thread within Cixous's theory of écriture feminine (p. 182). The notions of body and sensuality in Their Eyes along with other Hurston's novels have been always investigated by different scholars through different perspectives. However, the present article aims to deal with the concept of body and its inspection throughout the selected literary work. 


\section{Discussion}

\subsection{Hurston's Strong Devotion to the Notion of Body}

Regarding Cixous's well-known essay "The Laugh of the Medusa"; it is assumed that Hurston has applied what she (1988) impels a woman to do. Cixous encourages them to resist patriarchy by means of pushing their bodies into writing (p. 94). Moreover, in The Newly Born Woman, it is observed that Cixous (1988) appraises women's writing and its subversive quality where she asserts that:

Women have almost everything to write about femininity: about their sexuality, that is to say, about the infinite and mobile complexity of their becoming erotic, about the lightning ignitions of such a minusculevast region of their body.... (p. 94)

Through her words, Cixous proclaims that women are aware of the power that is concealed within their bodies. This quotation seems to be a defense against patriarchal psychoanalysts like Freud who have endeavored to define women's eroticism via their own patriarchal and phallocentric theories. In addition, Cixous invites women to write their bodies in order to resist omission from cultural arenas. By means of inscribing her body in the form of her text, Hurston has resisted death and confirmed her literary revival.

Hurston's consideration with corporeality is admitted by another critic who is called Zadie Smith (2009). She believes that Hurston's reputation is not a consequence of "the Black Female Literary Tradition", but this is her own self that makes her remarkable (p. 8)._According to Smith (2008), Hurston is "one of the truly eloquent writers of sex" and "is as exceptional among black women writers as Tolstoy is among white male writers" (p. 8). Within the former quotations, Smith asserts that Hurston is not as much involved with racial issues as her counterparts; instead she is concerned with the notion of reproductive roles and gender issues. Thus Hurston has incorporated what a typical woman undergoes due to her body and gender.

Another critic who points to Hurston's significance and the distinctive features of Their Eyes is Virginia Heffernan (2005). She considers Their Eyes as a "forceful, erotic, well-wrought story" which is suitable for post-structuralist analysis due to "its narrative technique" (2005). Heffernan's argument verifies the capability of this study as Cixous's theories provide a careful examination of the issue of eroticism which is a clear characteristic of the selected text.

Hurston's faint involvement with the issue of race is another notable aspect of her works. In Dust Tracks on a Road, Hurston (1996) states that she would like to examine "what makes a man or a woman do such-and- so, regardless of his color" (p. 151). Moreover, in one of her letters which appears in Kaplan's Zora Neale Hurston: A Life in Letters (2003), she claims that: "I belong to no race nor time. I am the eternal feminine with its strings of beads" (p. 58). The aforementioned quotation testify the capacity of Hurston's Their Eyes to be studied in the light of Hélène Cixous's poststructuralist feminist theories who is concerned with writing about woman as "a universal woman subject who must bring women to their senses and to their meaning in history" (1976, pp. 785-6). Cixous (1976) invites all women to put themselves into writing regardless of a particular ethnicity (p. 875). Concerning Cixous's invitation, the feminine quality and universality of Hurston's works are preferred over the ethnic and racial themes within them.

\subsection{Projection of Corporeality within Their Eyes Were Watching God}

To detect the manifestation of body within Their Eyes Were Watching God, this article aims to commence with the early paragraphs of the novel where the readers are encountered with the first exposure of body. This certain paragraph depicts Janie's womanly figure as she enters Eatonville in coveralls. The readers are faced with the gazing community who notice "her firm buttocks" which look like "grape fruits", her "great rope of black hair" that are entangled in the wind and her "pugnacious breasts" that seem to pierce her shirt (Hurston, 2006, p.2). While the male community tries to record this scene within its mind, the female community seeks for a weak point within Janie which is mainly her overalls.

There are disputable points are necessary to be discussed regarding the aforementioned passage. The first point to be mentioned here is that the story does not depict "an artist as an individual of high sensitivity with a portable pedestal" as Kubitschek (1983) convincingly argues, "but as a middle-aged, blue-jeaned woman talking with neighbors" (109). Through the portrayal of a woman who enters a communal scene at the outset of the novel, Hurston is therefore deconstructing issues of class and gender via her heroine, Janie.

The first three pages of the novel are competent to display Janie's power to confront with the oppressive attitudes of her community. Her beauty combined with strength is threatening to Eatonville's social system as the representative of an American hierarchical structure. Tom McGlamery (2004) asserts that Janie's organs have to be considered as "markers of an essentially undiminished "strength" that both sets in motion the anarchy at the heart of Eatonville and protects her from its effects" (p. 98). Therefore, McGlamery (2004) tries to refute the theory of gaze as a sign of power. He delineates his idea by uttering that: "Watchers are passive, weak, desirous, envious, feckless, helpless, ignorant, and enthralled" (p. 98). He considers spectating as a significance of "want" and states that "power belongs to the object of attention, who is often, in fact, God-like" (McGlammery, 2004, p. 98).

The narrator's persuasive claim that appears immediately after the formerly discussed paragraph within Their Eyes is debatable as a result of its capability to prove the argument about Janie's body as a sign and site of her empowerment: "But nobody moved, nobody spoke, nobody even thought to swallow spit until after her gate slammed behind her" (Hurston, 2006, p. 2). In addition, by applying adjectives like "firm" before "buttocks", "great" before "rope of black hair" and "pugnacious" before "breasts", Hurston is granting courage and power to Janie's organs and actions. 
When Janie hears women's laughter from outside she utters: "Well, Ah see Mouth-Almighty is still sittin' in de same place. And Ah reckon they got me up in they mouth now" (Hurston, 2006, p. 5). Quite like the narrator and writer's attitude that adapts Janie's hair and other corporal organs to indicate her beauty, Janie uses the gossiping woman's mouth; a reproductive part through which one speaks and eats to signify the woman who passes judgments on her.

Nearly the end of chapter one, Janie starts to narrate her story to Phoeby, since she views her as her "intimate" friend. Moreover, Phoeby is considered as her representative therefore Janie can "communicate with the community" through her (McGlamery, 2004, p. 112). She tells Phoeby: “Ah don't mean to bother with tellin' 'em nothin', Phoeby. 'Tain't worth de trouble. You can tell 'em what Ah say if you wants to. Dat's just de same as me 'cause mah tongue is in mah friend's mouf" (Hurston, 2006, p. 6). The last statement could be regarded as a metaphor since there are further meanings that are concealed beneath its surface. Jan Beneš (2011) points to the existence of a "homoerotic" vision within the statement "Mah tongue is in mah friend's mouf" by means of which Hurston attempts to sensualize Janie's narrative (25). In addition, it depicts a kind of union that in McGlamery's words "provides an image of generative coitus and narrative intimacy and trust" (p. 122). Hence, storytelling becomes a substitute for childbearing through which Janie achieves reproduction.

The second chapter of the novel is capable to disclose one of the most sensual scenes in American literature (Kaplan, 1996, p. 115). Janie's first erotic pleasure combined with her first self-revelation is portrayed and recounted while Phoeby is "listening hungrily" (Hurston, 2006, p. 10). There are two particular paragraphs that elucidate how a young woman is capable of fantasizing both marriage and intimacy. Moreover, they are open to reveal that a woman is willing to experience them quite naturally and organically. They portray Janie as she is lying down under a "blossoming pear tree" in "a spring afternoon" (p. 10). She is fascinated by the blooms and the bees that revolve around and sink in them (p. 11). This natural romantic scene unfolds the undeniable verities about her womanhood that have "buried themselves in her flesh" and thus point to her sensual awakening (pp. 10-11). The "bloom" is a sign of Janie's burgeoning libido. She questions the birth of natural elements by asking: "What? How? Why?" (p. 10). All of the elements of song, music and nature as well as literary effects are interwoven impressively. The whiteness and purity of the blossoms are compared to a young virgin and nature is compared to a rose which is disseminating its lure odor around. Except the sense of taste, the passage includes the four external senses of smell, audition, touch and vision which indicate plurality of senses and thus plurality of a feminine jouissance. In addition to the previously mentioned similes, there are several other terms that point to marital bliss. The "bees" and "blooms" that astounds Janie, the "panting breath of the breeze", "the love embrace", "ecstatic shiver", along with "a pain remorseless sweet", as well as being "limp and languid" contain suggestive overtones, which indicate how Janie, as a typical woman idealizes marriage by means of her imagination and intuitions (Hurston, 2006, pp. 10-11). Cixous's proclamation within her essay The Laugh of the Medusa endorses Janie's experience where she states: "Women's imaginary is inexhaustible, like music, painting, writing: their stream of phantasms is incredible" (p. 875). In fact, her declaration justifies capacity of inexhaustible illusion that is possessed by Hurston as a female author and Janie as a female personality.

Influenced by nature, Janie commences her search for love and fulfillment immediately when she witnesses "flies tumbling and singing, marrying and giving in marriage" inside the kitchen (Hurston, 2006, 11). McGlamery (2006) argues that this recent scene is more debatable than the bee imagery since it "incorporates elements of communal play, role interchange, and hierarchical dissolution" (p. 105). Therefore, it displays a community with no gender limits where a woman is allowed to enter the plays and is not supposed to "class off" (McGlamery, 2006, 105).

Impressed by the marrying bees, Janie lets Johnny Taylor kiss her. Unfortunately, Nanny witnesses her and pushes Janie into marriage with Logan Killicks because she regards sensuality as harmful and threatening. Nanny's aim is to protect Janie from everything that harmed her Leafy, Janie's mother (Hurston, 2006, p. 12). Upon Janie's protest and sob, Nanny begins to narrate the story of her enslavement and Leafy's being sexually assaulted to Janie. Hereby, Nanny declares her theory of black woman's enslavement where she states that "De nigger woman is de mule uh de world so fur as Ah can see" (Hurston, 2006, p. 14). Nanny's theory later becomes the site of critics' discussions. Through this theory, the distribution of power is classified according to the categorization of gender and race. In this gender classification, the black woman has been allotted the lowest level. Therefore, she becomes double-exploited as a result of being both black and female. Nanny continues her speech by narrating how she was exploited, assaulted and impregnated by his white master until the abolishment of slavery. She utters how she underwent an assault by her master after childbirth for the last time and tells Janie: "But pretty soon he let on he forgot somethin' and run into mah cabin and made me let down mah hair for de last time. He sorta wropped his hand in it, pulled mah big toe, lak he always done, and was gone after de rest lak lightning" (Hurston, 2006, p. 17). Within these lines, Hurston applies euphemism to indicate the harsh assault that Nanny underwent. Another point about these sentences is that Nanny does not feel the confidence within herself to resist enslavement perhaps as a consequence of the historical phase when she was located or as a result of her acceptance of the situation.

After Nanny's story, this is Leafy's story of being attacked that has to be recounted to Janie. This incident is considered as the main cause of Nanny's fear of Janie's awakening sensuality. Nanny is frightened of her "sex"; of being a woman due to the colonization of her body by patriarchy. This fact has restrained her from "exploring" her body and makes her prevent Janie from "exploring" and "enjoying", as well. Patriarchal system leads to Nanny and Janie's hatred of each other. As Cixous (1988) writes: "Woman is disgusted by woman and fears her" (p. 68). Thus patriarchy's worst cruelty is leading women to detest themselves and "to be their own enemies, to mobilize their immense power against themselves" (Cixous \& Clement, 68). 
Another feminine aspect of Hurston's opus is her attempt to provide new ways of defining female beauty. For this purpose, Hurston praises the beauty of other women in her story in addition to glorifying the beauty of her heroine, on some occasions. There are two paragraphs within chapter six of Their Eyes where other female characters' beauty and femininity is delineated. The first scene is displayed as Daisy enters Joe Starks's store porch. The definition of her manners is intriguing where Hurston (2006), recounts that she "is walking in a drum tune" (68). The writer praises Daisy's black eyes that "shine like brand new money" as well. It is also notable that Daisy "Knows what God gave eyelashes for, too" (p. 68). The related passage is unique in its attempt to celebrate black features. It is deconstructive in the sense that it does not follow the ordinary western male texts that praise white skin, blue eyes and blonde hair. In addition, it indicates a woman's awareness of her own beauty, which is a meaningful factor in order to value one's own femininity. A further disputable point lies in Hurston's attempt to compare Daisy's eyes to money and her hair to food when she writes that her hair is "like the piece of string out of a ham. It's not ham at all, but it's been around ham and got the flavor" (Hurston, 2006, p. 68). The desire for victuals and wealth along with procreation are the objects of almost all people's desire. Their Eyes is replete with images that are related to food or mouth, a digestive as well as oral organ. In addition to the presence of "Mouth-Almighty", a gossiping figure who has Janie in her mouth (p. 5), there is a community who "passed nations through their mouths" (p. 1). As McGlamery (2006) also points, the "back parts" of the community's minds are "chewed up" and "swallowed with relish" (p. 2). Janie's hips look like grape fruits. The other similar scenes are Pearl Stone's mouth opening as well as Mrs. Sumpkins suckling her teeth (Hurston, Their Eyes 3). McGlamery (2006) considers these points as results of "lack of emotional and intellectual resources for dealing with the vision of Janie" (p. 97). Yet the existence of similar visions about other women within the community like Daisy is an evidence of such attitudes toward their appeal. The reason that the male community fantasizes their female citizens might be concealed in the fact that they do not possess the power to resist women's empowerment in addition to their incapability in having them.

Body and resistance toward patriarchy are closely connected together within this story. Joe Starks (Jody) confines Janie in several ways. He inflicts wearing kerchief on her head. In addition, he restricts her between the borders of his mansion and store, forbidding her from participating in community gatherings or delivering a speech on similar occasions and even enjoying the stories or lying contests that are performed on his store porch. It is one of these lying contests that Mrs. Boggle's arrives with her "blushing air of coquetry" despite of her being "many times a grandmother" (p. 69). Joe demands Janie to go and take her orders in spite of her enthusiasm for hearing "the rest of the play-acting" (Hurston, 2006, p. 70). Janie's irritation is followed by a quarrel over a bill, which ends in Joe's humiliating Janie and accusing her of the occurred inconvenience. Janie accedes that she has no other way than to submit and their marriage is in this way troubled. She ascertains that "[t]he spirit of marriage left the bedroom and took to living in the parlor" (Hurston, 2006, p. 71). She is reduced to a picture of "Virgin Mary" in the church and her marital bed does not represent "a daisy-field" anymore" which conveys Janie's sex-less marriage (p. 71). The "spirit of marriage" could be considered as a metaphoric term regarding marital bliss between Janie and her husband in the researcher's point of view. The "Virgin Mary" is the significance of Janie who is deprived of a satisfactory marital intimacy and thus does not reach sensual fulfillment in her marriage.

Occasionally, Hurston's marionettes insult and degrade each other by means of obscenity. Jody's arrogance restrains him from admitting his aging that is demonstrated in his weakening knees, ankles and belly that "sagged like a load suspended from his loins" in addition to his absent eyes (p. 77). Therefore, he does his best to decrease his anxieties by revolving the gazing eyes from his own body to Janie's. He denigrates her by calling her "no young pullet" or "ole hen" (Hurston, 2006, p. 77). The last time that he ventures to scorn Janie in front of community's eyes, he alleges that Janie is as old as the biblical Methuselah due to her failure in cutting the tobacco straightly. Janie refuses to remain silent this time and argues: "When you git through tellin' me how tuh cut uh plug uh tobacco, then you kin tell me whether mah behind is on straight or not" (Hurston, 2006, p. 78). Additionally, she accuses Joe of "talkin' under people's clothes" and thereafter she declares that she is a woman in every inch of herself in addition to claiming that this is Joe who represents the change of life (p. 79). By calling Janie "Methusalem", Jody is falsely accusing Janie of reproductive incapability and this is indeed another attempt to transmit the community's attentions to Janie. Janie cannot stand his challenges anymore, thus enters the battlefield to defend her femininity as well as sensuality. She assures that she is young, healthy and "woman" (p. 79). As a consequence, Janie transgresses her limited female territory and enters the public maledominated territory and fulfills what Cixous (1988) commands women to do; she writes her body. In other words, Hurston writes her body in her text. Both Hurston and her heroine Janie gain "the unimpeded tongue that bursts partitions, classes, and rhetorics, orders and codes, ..." (Cixous \& Clement, pp. 94-5). Since, by adapting the concept of corporeality, Hurston succeeded in eliminating the male-dominated cultural notions that imposed various restrictions on her. The passage that is under discussion is also referent to Irigaray's comment about women's libido who claims that women's pleasure is multiple as the result of their multiple reproductive organs (1985, p. 233).

Tea Cake is Janie's man of dreams and their marriage leads to Janie's fulfillment. This is not due to his "full, lazy eyes with the lashes curling sharply away like drawn scimitars" or his "lean, over-padded shoulders" (Hurston, 2006, p. 106). He seems to Janie "like the love thoughts of women" and reminds her of "a bee to a blossom in the spring." In addition, Janie's intuition is that "He was a glance from God" (Hurston, 2006, p. 106). Tea Cake's appealing manners are basically the results of his naturalness and unconventionality. Since he does not believe in hierarchical system of values similar to other members of their society, he falls in love with Janie who is nearly a decade older than him, admires her beauty and expresses this to her, combs her hair and even scratches the dandruff from her head (Hurston, 2006, p.103). 
They marry and "the two began an organic and passionate affair", leaving Eatonville for the muck of the Everglades thereafter (King, 2008).

Despite their organic and romantic union, there are occasions when Janie applies her body's roughness to resist Tea Cake's disloyalty and infidelities. Janie tries to beat Tea Cake, when he impertinently returns to Janie after his relationship with Nunkie is uncovered. Janie's physical attack is a remedy to her natural jealousy and she continues the struggle until both of them submit, reunite and sleep "in sweet exhaustion" (p. 138). Thus their mild tension ends in a "sexual ecstasy" in Jennifer Jordan's point of view (1988, p. 112).

The last debatable site of body in Their Eyes Were Watching God to be mentioned is related to Mr. and Mrs. Turner. For Janie, love and marital bliss are interconnected; hence the second is a sign of the existence of the first. Love paves her way to reach sensual fulfillment and thus self-realization. In contrast to Janie and Tea Cake, the Turner couple does not live a satisfactory and respectable marital life due to their loveless marriage. Consequently, Mr. Turner says Tea Cake: “Ah reckon you ain't 'cause dey all passed on befo' dis one wuz born. ain't had no luck at all wid our chillun. We lucky to raise him. He's de last stroke of exhausted nature" (Hurston, 2006, p. 144). The phrase "exhausted nature" refers to the lack of natural generative satisfaction in Turner couple.

Thus far, this paper has inspected the debatable sites of 'body' within Their Eyes. As it has been observed, there are multitudes of references to the mentioned issue. In sum, it can be assumed that Hurston is concerned with it in her work. Indeed, Hurston does not attempt to commit self-censorship. This article has also endeavored to present the significance of the selected issue in the light of Hélène Cixous's feminist philosophy.

\section{Conclusion}

A substantial characteristic of a post-structuralist text is undoubtedly its attempt to adapt the notions of body and corporeality in order to challenge logocentric and phallocentric thought. As it has been noticed there are multitudes of examples and excerpts within Their Eyes that are abundant with erotic qualities. The most sensual passage of the American literature appears in Their Eyes Were Watching God according to Kaplan (1996). It implies Hurston's commitment to incorporating physicality within her fictional work. With regard to the former discussions, the harassments that different women undergo are depicted in a metaphoric way. Nanny's indication of being assaulted by her master is revealed in euphemism. This can be considered as one of Hurston's methods of eliminating censorship. There are also profuse references to the heroine's desire for self-expression, fulfillment and empowerment Their Eyes which are achieved by recognizing her womanhood and her longings. Therefore, both Hurston and Janie refuse to practice self-censorship by means of which they follow the pre-requisite condition of 'writing the body' or in other words, écriture féminine.

Another dimension of this research regards the application of body within critical and cultural studies, which is limited to feminist theories of Cixous in this debate. Cixous's 'Writing the body' is a powerful means to deconstruct patriarchal beliefs and phallogocentric laws that reside within the cultural and societal systems of thought. In conclusion, Hurston has taken advantage of her libidinal writing in order to resist the phallogocentric confinements that attempted to prevent her from writing, literary production and being a public figure due to her sex, color and race in addition to her not being extremely concerned with racial and ethnic issues in some occasions. Janie, the heroine of Their Eyes applies her body as a weapon to rebel against the patriarchal conventions, oppressions and repressions and becomes successful in subverting most of them. At last, Janie reaches self-actualization by taking her body into consideration.

\section{References}

Beneš, J. (2011). Discourse on sexuality in the works of Zora Neale Hurston. Dissertation. Masaryk University. Available from Masaryk University Information System. Retrieved from http:/www./th/179234/ff_m/.

Cixous, H. (1976). The laugh of the medusa. Signs, 1, 875-893.

Cixous, H. (1988). Sorties. In Cixous, H. \& Clément, C. (2nd ed), The newly born woman (pp. 63-130). Minneapolis: University of Minnesota Press.

Eagleton, M. (1996). Working with feminist criticism. (pp. 172-178). Oxford: Blackwell and Wiley Publishers.

Heffernan, V. (2005). A woman on a quest, via Hurston and Oprah. The New York Times. Retrieved from http://v.nytimes.com/2005/03/04/arts/television/04heff. html?n=Top/Reference/Times Topics/People/H/Hurston, Zora Neale\&_r $=0$

Hurston, Z. N. (1996). Dust tracks on a road. (p. 151). New York: Harper Perennial.

Hurston, Z. N. (2006). Their eyes were watching God. New York: Harper Perennial Classics.

Irigaray, L. (1985). The sex which is not one. New York: Cornell University Press.

Jordan, J. (1988). Feminist fantasies: Zora Neale Hurston's Their Eyes Were Watching God. Tulsa Studies in Women's Literature, 7(1), 105-117.

Kaplan, C. (1996). The erotics of talk; women's writings and feminist paradigms. (1st ed). New York: Oxford University Press.

Kaplan, C. (2003). Zora Neale Hurston: A life in letters. New York: First Anchor Books Editions.

King, L. (2008). The Cambridge introduction to Zora Neale Hurston. Cambridge: Cambridge University Press.

Kubitschek, M. D. (1983). "tuh the horizon and back": The female quest in their eyes were watching God. Black American Literature Forum, 2(29), 109-115.

McGlammery, T. (2004). Protest and body in Melville, Dos passos, and Hurston. (pp. 91-123). New York: Routledge. Smith, Z. (2009). Changing my mind: Occasional essays. New York: The Penguin Press. 